\title{
SEXUALITY IN WOMEN AFTER HYSTERECTOMY
}

\author{
Sawitri B*, Muhdi N** \\ * Dokter Umum, Peserta PPDS I Prodi Psikiatri Departemen/SMF Ilmu Kedokteran Jiwa FK UNAIR/RSUD dr. Soetomo Surabaya \\ **Guru Besar, Psikiater Konsultan, Staf Pengajar Departemen/SMF Ilmu Kedokteran Jiwa FK UNAIR/RSUD dr. Soetomo Surabaya
}

\begin{abstract}
Hysterectomy is the most common major gynecological surgeries, with up to 39,4\% women will experience it during her lifetime. This procedure can be stressful for women as half of them will experience mild to severe physical and psychological complications. Uterus removal is often associated with de-feminization, castration, being disabled and loss of wholeness which may alter body image and self-esteem, ultimately lead to depression. Most women are anxious on how hysterectomy affect their sexuality, but only few feel comfortable discussing this essential matter to health professionals. The evaluation and management of sexual dysfunction had been the traditional province of psychiatrist. Psychiatrists should fulfill their competencies by updating knowledge on sexuality and sexual dysfunction, improving communication skill, being comfortable with own sexuality and discussing sexuality with other. Pharmacotherapy, relaxation techniques, behavior therapy, group therapy, analytical oriented sex therapy, dual-sex therapy and other techniques or exercises are some modalities option which may help women with sexual difficulties post-hysterectomy.
\end{abstract}

Keywords: women, sexuality, hysterectomy

Corresponding author: Brihastami S, dr.

Dep/SMF Kedokteran Jiwa FK UNAIR/RSUD Dr.Soetomo Surabaya HP: 0818322841 | email: brihastami-s@fk.unair.ac.id 


\section{PENDAHULUAN}

Histerektomi merupakan pembedahan mayor tersering pada ginekologi serta salah satu tersering pada perempuan usia reproduktif. Prosedur ini dapat menimbulkan tekanan terkait pembedahan dan potensi komplikasi pasca operasi, berkorelasi dengan kecemasan, depresi, perubahan harga diri dan fungsi seksual. Hubungan terhadap kemampuan memiliki anak dikaitkan dengan femininitas dan makna keutuhan bagi banyak perempuan. Banyak yang mengkhawatirkan pengaruh histerektomi pada kehidupan seksual namun sedikit yang nyaman mengungkapkannya. Mereka yang paham sebelum operasi cenderung lebih relaks serta mendapat hasil lebih baik [1-4].

Persiapan psikologis merupakan bagian penting pra operasi. Kekhawatiran fungsi seksual pasca histerektomi merupakan kecemasan tersering. Evaluasi dan manajemen gangguan seksual merupakan wewenang psikiater dibanding profesi lainnya. Konsultasi departemen Obstetri Ginekologi (ObGin) pada Consultation Liaison Psychiatry (CLP) d sangat rendah $(0,11 \%)$ di banyak negara. Peningkatan kolaborasi antara ginekolog dan psikiater meningkatkan perawatan holistik yang lebih baik bagi pasien [3-7].

\section{PEMBAHASAN}

Seksualitas merupakan aspek integral kepribadian, lebih sekedar kontak seksual atau kemampuan mencapai kepuasan seksual, mencakup bagaimana memandang gender diri, perasaan mengenai tubuh (body image), serta komunikasi verbal/non-verbalnya. Seksualitas tidak berakhir di usia tertentu, diagnosis atau setelah prosedur tertentu. Seksualitas dan keintiman bahkan semakin penting sebagai cara re-afirmasi hubungan manusia, gairah hidup dan rasa diinginkan yang terus berlanjut. Seksualitas merupakan aspek penting kualitas hidup yang sering diabaikan profesi kesehatan. [5,8-10]

Kontras dengan ketakutan efek negatif histerektomi pada fungsi seksual, banyak yang mengalami peningkatan fungsi, frekuensi dan orgasme, serta berkurangnya nyeri, utamanya pasca histerektomi mengatasi perdarahan disfungsional uterus. Kepuasan seksual cenderung membaik pada histerektomi vaginal, subtotal (serviks intak) dan total (uterus dan serviks diangkat). Namun perempuan dengan riwayat depresi sebelumnya cenderung mengalami perburukan fungsi seksual pasca histerektomi $[8,11]$.

\section{Efek Histerektomi pada Seksualitas}

1. Dispareunia pasca histerektomi diperkirakan pada 2-7\% perempan dan diakibatkan pemendekan bahkan fibrosis vaginal. Namun panjang vagina seringkali tetap, bahkan tidak berkorelasi dengan fungsi seksual. Dispareunia kronis mengakibatkan penghindaran hubungan seksual yang berdampak negatif pada keintiman emosional dan hubungan pribadi [5.12].

2. Vagina kering terjadi pada $9-21 \%$ perempuan, berkontribusi terhadap dispareunia. Kondisi ini umumnya membaik, terutama dengan terapi sulih hormon [5,12].

3. Masalah orgasme dilaporkan pada $2-11 \%$ perempuan. Peran serviks pada respon seksual telah diperdebatkan sejak penelitian Masters dan Johnson, meski tidak ditemukan perbedaan frekuensi intercourse, orgasme multipel, derajat lubrikasi dan penilaian hubungan seksual oleh pasangan pada histerektomi total dan subtotal. Pengangkatan serviks tidak mengganggu ujung saraf pleksus uterovaginal, bahkan orgasme meningkat pada $80 \%$ pasien histerektomi dengan/tanpa ovarektomi bilateral. Lokus orgasme yang sering dilaporkan adalah klitoris (30\%), klitoris-vagina (13\%), vagina $(11 \%)$, uterus dan uterus-vagina (8\%). Orgasme 'eksternal' akibat stimulasi klitoris tidak dipengaruhi histerektomi. Mayoritas (75-92\%) perempuan merasa stimulasi payudara meningkatkan respon orgasme dan tidak menurun pasca histerektomi/ovarektomi [5,12-15].

4. Libido (hasrat berhubungan seksual dan ketertarikan seksual) dilaporkan menurun pada 5-11\% perempuan dan membaik pada 60-100\%. Libido rendah dihubungkan dengan riwayat rendah sebelumnya. Menopause akibat pembedahan meningkatkan risiko penurunan libido atau Hypoactive Sexual Desire Disorder (HSDD) yang umumnya teratasi dengan estrogen dan sebagian kecil dengan androgen $[12,15,16]$.

5. Citra tubuh dan diri dilaporkan membaik pada 
6. $46 \%$ perempuan pasca histerektomi abdominal total, subtotal atau vaginal, dibandingkan $25 \%$ yang memburuk. Hanya $10 \%$ yang melaporkan berkurangnya femininitas, sementara $70 \%$ tidak merasakan perubahan [12].

7. Fungsi ovarium sebagai penghasil estrogen dan testosteron penting dalam mengatur fungsi seksual, mempengaruhi libido, arousal dan orgasme. Estrogen membantu aliran darah menuju vagina dan klitoris, lubrikasi dan keseluruhan kesehatan vagina. Insufisiensi androgen dikaitkan hilangnya respon efektif terhadap stimuli seksual, serta kemungkinan gangguan kongesti vulva dan vagina. Ovarektomi juga dihubungkan dengan ambivalensi terhadap histerektomi, kekacauan emosional atau depresi terkait terapi sulih hormon, bersama dengan perasaan penuaan dini atau perubahan citra tubuh [12].

\section{Patofisiologi Female Sexual Dysfunction Pasca Histerektomi}

Fungsi seksual perempuan bergantung pada komponen psikologis dan fisiologis (hormonal dan anatomis):

1. Faktor Psikologis

Banyak aspek fungsi seksual perempuan (termasuk hasrat seksual, orgasme dan kepuasan seksual) dipengaruhi oleh gejala depresi. Depresi lebih banyak dilaporkan pasca histerektomi dibanding pembedahan lain pada usia dan waktu yang sama. Namun semakin banyak studi menunjukkan perbaikan gejala psikologis dan well-being pasca histerektomi untuk menorrhagia ringan. Gejala depresi pasca histerektomi untuk kondisi jinak dilaporkan lebih ringan dibandingkan tanpa terapi. Kepuasan hidup perempuan usia lanjut pasca histerektomi serupa bahkan lebih baik dibandingkan yang tidak menjalani $[9,17,18]$.

Kebanyakan fungsi kejiwaan cenderung membaik pasca histerektomi total dengan/tanpa ovarektomi bilateral untuk keluhan menorrhagia, nyeri panggul dan sindroma pra menstrual berat. Faktor risiko yang meningkatkan reaksi psikologis yang tidak diinginkan pasca histerektomi antara lain; usia muda ( $<35$ tahun), histerektomi sebagai tindakan emergensi, dukungan sosial kurang, pernikahan disfungsional, status sosioekonomi rendah, riwayat pembedahan ulang, riwayat diri atau keluarga dengan depresi atau gangguan mental lain, masalah identitas seksual, ingin memiliki anak, takut kehilangan daya tarik seksual, sikap negatif pada pasangan, serta pasangan yang menganggur [11], [19].

Sebagian besar perbaikan fungsi seksual pasca histerektomi dikarenakan perbaikan gejala psikologis, keluhan kesehatan dan psikosomatik keluhan ginekologis. Perbaikan seksual lebih positif pada mereka dengan gangguan lebih berat sebelumnya. Berhentinya siklus menstruasi dan kekhawatiran hamil dipandang sebagai kontributor positif [1], [9].

Hasrat seksual dapat turun karena takut hubungan seksual akan mengganggu luka operasi. Pasangan mungkin berpikiran serupa, meski hal ini tidak memungkinkan setelah luka dinyatakan sembuh. Sangat membantu jika pasien setuju menyertakan pasangan/keluarga saat mendiskusikan histerektomi. Perlu ditekankan bahwa pembedahan dapat menimbulkan stres dan membutuhkan mobilisasi sumber daya personal, termasuk keluarga dan teman [3], [4].

Beberapa perempuan memandang diri mengalami de-feminisasi, berduka terhadap akhir kemampuan memiliki anak, kehilangan atau kehampaan dan citra tubuh negatif karena bekas luka atau perubahan hormonal. Semua ini mempengaruhi seksualitas, meski durasi dan besar dampaknya belum diketahui. Kecemasan pra operasi mengenai seksualitas berkorelasi dengan penurunan hasrat dan dispareunia lebih berat setelahnya $[5,9,18]$.

Depresi didapatkan pada $28 \%$ perempuan menjelang histerektomi. Mereka dengan depresi sebelumnya tidak mengalami perbaikan fungsi seksual, berkorelasi dengan perburukan gejala seperti nyeri panggul dan punggung, terbatasnya aktivitas, gangguan tidur, kelelahan, pembengkakan abdomen dan inkontinensia urinaria pasca operasi $[5,15,20]$.

Prediktor utama disfungsi seksual pasca histerektomi termasuk disfungsi seksual, depresi, hubungan buruk dengan pasangan dan kurangnya dukungan sebelum pembedahan. Faktor pasca operasi yang penting antara lain ketidakpuasan pada indikasi dan 
hasil operasi, perubahan persepsi citra diri dan tubuh, serta perubahan fisik dan hormonal $[5,12]$.

Komunikasi seksual dapat bermasalah. Perdarahan vagina dapat mengurangi libido, lubrikasi dan orgasme, menimbulkan rasa bersalah dan insecure sebagai pasangan seksual yang "tidak baik". Dari 3.807 perempuan, $40 \%$ tidak melapor pada dokter keluhan seksualnya meski 54\% menyatakan ingin. Hanya 39\% yang merasa dokter menganggap serius keluhan mereka. Penting untuk profesi medis lebih peka dan membicarakan aspek psikologis keluhan seksual [15].

2. Faktor Hormonal

Histerektomi dapat mempercepat kegagalan ovarium dan menopause meski ovarium dipertahankan. Ovarektomi cenderung menghasilkan outcome seksual lebih buruk. Setidaknya satu ovarium diangkat pada separuh histerektomi di Amerika Serikat. Pengangkatan kedua ovarium menginduksi surgical menopause melalui penurunan drastis kadar estrogen, testosteron dan hormon seks lain. Estrogen dan testosteron memodulasi jaras otonomik pelvis. Reseptor estrogen banyak diekspresikan saraf simpatis, terutama inervasi simpatis uterus. Estrogen meningkatkan aliran darah dan lubrikasi, sementara tertosteron meningkatkan hasrat seksual, rangsangan subyektif dan sensasi seksual $[5,9,21]$.

Penurunan drastis estrogen sering mengakibatkan hot flushes yang sangat mengganggu, sampai mengakibatkan gangguan tidur dan depresi. Estrogen (tanpa progresteron) meringankan gejala dan mengurangi salah satu penyebab depresi pasca operasi. Testosteron merupakan hormon kunci yang mempengaruhi dorongan dan respon seksual. Separuh testosteron perempuan diproduksi di ovarium, sisanya oleh kelenjar adrenal. Histerektomi tanpa ovarektomi dapat mengubah aliran darah ke ovarium yang menurunkan produksi hormon (termasuk testosteron) sehingga hasrat seksual menurun meski ovarium intak $[3,4,11]$.

Perempuan tanpa terapi sulih hormon pasca histerektomi-ovarektomi mengalami rangsangan subyektif lebih rendah, dispareunia dan keluhan seksual umum lebih banyak. Meski keamanan dan efektifitas androgen dosis rendah belum dapat dipastikan, terapi sulih hormon estrogen dengan androgen menunjukkan perbaikan aspek seksual yang lebih dibanding estrogen saja $[5,9]$.

3. Faktor Anatomi

Histerektomi sering mencakup pengangkatan jaringan sakit (seperti fibroid) yang menyebabkan nyeri aktivitas seksual. Dispareunia merupakan gejala umum gangguan ginekologis dan berkurang signifikan pasca histerektomi. Histerektomi mempengaruhi inervasi saraf otonom yang banyak terdapat pada organ genital internal dan sangat penting pada fungsi seksual melalui eksisi pada serviks dan pemisahan uterus dari ligamen pendukung. Kerusakan saraf pada histerektomi dapat mengubah fungsi pelvis, mengakibatkan disfungsi seksual, berkemih maupun defekasi. Randomized clinical trial oleh Thakar et al. (2002) membuktikan tidak ada perbedaan signifikan antara histerektomi total dan supraservikal terhadap seksualitas. Meski berdampak minimal pada kemampuan orgasme, intensitas subyektif dan kenikmatan orgasme mungkin berubah pada sepertiga perempuan. Pengangkatan uterus dapat mempengaruhi seksualitas dimana kontraksi uterus dikaitkan dengan orgasme dan rangsang seksual $[5,8,9,14,22]$.

Pembedahan pada perempuan dengan masalah seksual sebelumnya dapat mengurangi maupun mengekaserbasi gejala. Pada 1 dari 5 perempuan tanpa masalah seksual sebelumnya, terdapat setidaknya 1 gejala seksual yang mengganggu pasca pembedahan. Pada 1.101 perempuan usia 35-49 tahun $(89,2 \%$ pra menopause dan $43 \%$ menjalani ovarektomi bilateral), dilakukan penilaian seksual sebelum dan pada 6, 12, 18, 24 bulan pasca histerektomi. Perempuan yang berhubungan seksual meningkat $(70,5 \%$ ke $77,6 \%)$, dispareunia menurun $(18,6 \%$ ke $3,6 \%)$ dan anorgasme menurun $(7,6 \%$ ke $4,9 \%)$. Keluhan vagina kering dan libido rendah juga menurun signifikan. Meski terdapat rata-rata perbaikan $60 \%$ untuk keluhan seksual, terdapat $10 \%$ yang tidak bermasalah sebelumnya menjadi tidak aktif secara seksual. Dari yang aktif, 9,4\% mengeluh vagina kering, 2,3\% anorgasme, 5,2\% libido rendah dan $2 \%$ merasakan dispareunia 24 bulan pasca histerektomi $[5,15]$.

Kualitas, fungsi dan masalah seksual, berkorelasi dengan usia, ras, masalah kesehatan mental, masalah hubungan 
dan berbagai kondisi sosioekonomi sebelum dan sesudah histerektomi. Faktor psikososial yang positif terhadap fungsi seksual antara lain hubungan yang sehat dengan pasangan, kesehatan umum yang baik dari keduanya, bebas dari tekanan hidup berat dan tidak adanya kekhawatiran finansial $[8,9,15,20]$.

\section{Faktor yang Mempengaruhi Adaptasi Psikoseksual Pasca Histerektomi}

1. Usia: Histerektomi sering terjadi di akhir masa fertilitas. Perubahan anatomi pasca menopause (pemendekan vagina, penipisan jaringan vagina dan labia minor, kurangnya lubrikasi dan elastisitas vagina serta sensitivitas klitoris, penyusutan labia mayor dan klitoris, menurunnya tonus otot perineum, frekuensi dan kualitas orgasme, yang mengakibatkan sexual arousal dan lubrikasi butuh waktu lebih lama) dapat rancu dengan dampak histerektomi.

2. Hormon: Ovarektomi pada histerektomi dapat mengakibatkan kekeringan vagina dan dispareunia. Terapi sulih hormon merupakan faktor signifikan adaptasi psikoseksual.

3. Tipe histerektomi: Pembedahan laparoskopik umumnya menghasilkan kualitas hidup lebih baik.

4. Kultur: Beberapa kelompok etnik lebih sulit menerima histerektomi. Perempuan India Barat yang merasa menstruasi berperan membersihkan dan menyucikan tubuh, takut suami menganggap 'cacat' dan mencari 'perempuan yang utuh'.

5. Pasangan seksual: Kepuasan perempuan terhadap hubungan dengan pasangan, usia pasangan, kesulitan ereksi pasangan, ejakulasi dini, penyakit kronis dan obat yang dikonsumsi pasangan mempengaruhi adaptasi psikoseksual. Pasien dengan hubungan buruk mengalami perburukan sexual arousal.

6. Makna uterus bagi perempuan: Banyak perempuan memandang uterus sebagai organ fertilitas, kecantikan seksual, organ sekretori, regulator fungsi tubuh, sumber energi, masa muda, kecantikan, daya tarik dan kekuatan. Mereka memandang operasi sebagai kehilangan masa muda, feminitas dan kesehatan. Mereka takut kehilangan daya tarik fisik dan identitas seksual, tidak berdaya dan depresi.
7. Perbaikan gejala penyakit penyebab histerektomi: Korelasi kuat didapatkan dengan keluhan sebelumnya. Bagi mereka dengan nyeri atau perdarahan hebat akibat mioma uterus, redanya sumber masalah memiliki efek positif pada seksualitas. Nyeri sexual intercourse berkurang pasca histerektomi akibat fibroid atau endometriosis. Histerektomi menurunkan perdarahan abnormal, nyeri panggul, depresi dan ansietas.

8. Reaksi psikologis perempuan terhadap operasi: Terdapat korelasi reaksi psikologis dengan persepsi perempuan terhadap pembedahan dan organ tersebut. Pendukung Freud percaya penurunan respon seksual akibat kehilangan organ seksual menyebabkan suatu kastrasi, meski intensitasnya bervariasi dan tidak semua mengalami $[9,19,23,24]$.

\section{Penatalaksanaan}

Psikiater adalah komunikator handal, namun memulai diskusi seksualitas dapat menimbulkan cemas. Lebih baik berasumsi pasien memiliki pertanyaan mengenai dampak penyakit/terapi pada seksualitas mereka. Pasien sangat menghargai pertanyaan aspek ini terkait penyakitnya. Banyak profesional kesehatan memakai model BETTER (Tabel 1.1) atau PLISSIT (Tabel 1.2) untuk membantu membicarakan seksualitas dan masalah seksual pasien [10,25].

Area kompetensi dalam menyertakan seksualitas dalam praktek mencakup kenyamanan seksualitas diri dan mendiskusikan seksualitas, ketrampilan komunikasi yang sangat baik, pengetahuan dasar seksualitas dalam kesehatan dan penyakit, serta role model yang mengintegrasikan seksualitas dalam praktek klinisnya sehingga membantu rekannya melalui berbagi pengalaman positif mendiskusikan seksualitas, bermain peran dalam berbagai cara memulai diskusi seksualitas dan sebagai sumber informasi. Visite dan presentasi kasus dapat meningkatkan kenyamanan untuk menyertakan diskusi seksual dalam praktik harian. Mengetahui sikap seseorang mengenai variasi perilaku seksual yang dapat diterima dan orientasi seksual merupakan langkah pertama agar merasa lebih nyaman [10]. 


\begin{tabular}{|c|c|}
\hline Bringing up the topic & $\begin{array}{l}\text { Sebelum pulang, saya ingin memberi kesempatan anda bertanya apa saja mengenai } \\
\text { hubungan seksual pasca histerektomi }\end{array}$ \\
\hline $\begin{array}{l}\text { Explaining: } \\
\text { seks merupakan bagian vital } \\
\text { dalam hidup }\end{array}$ & $\begin{array}{l}\text { Perempuan sering malu membicarakannya, tapi dokter dan perawat di sini sudah terbiasa } \\
\text { dan menemukan banyak yang memiliki pertanyaan mengenai aspek penting kehidupan ini. }\end{array}$ \\
\hline $\begin{array}{l}\text { Telling patients: } \\
\text { sumber informasi tersedia } \\
\text { untuk mereka }\end{array}$ & $\begin{array}{l}\text { Saya memiliki daftar buku yang mungkin menarik untuk anda mengenai berbagai aspek } \\
\text { pengalaman dengan histerektomi yang mungkin akan sangat membantu. }\end{array}$ \\
\hline $\begin{array}{l}\text { Timing of intervention: } \\
\text { menyesuaikan kebutuhan } \\
\text { pasien }\end{array}$ & $\begin{array}{l}\text { Mungkin kita dapat membicarakannya nanti siang atau anda dapat menelepon unit kami } \\
\text { kapanpun untuk menanyakan hal ini atau hal lain yang belum dibahas. Dokter anda juga } \\
\text { dapat menjawab jika anda rasa lebih nyaman. }\end{array}$ \\
\hline $\begin{array}{l}\text { Education: } \\
\text { efek samping seksual dari } \\
\text { terapi }\end{array}$ & $\begin{array}{l}\text { Kebanyakan perempuan melaporkan setelah operasi kehidupan seksual mereka kembali } \\
\text { seperti sebelum ada gejala penyakit. Bagaimanapun, anda mungkin merasakan perbedaan } \\
\text { saat orgasme karena rahim yang biasanya berkontraksi tidak lagi ada. }\end{array}$ \\
\hline $\begin{array}{l}\text { Recording: } \\
\text { catat pada rekam medis }\end{array}$ & $\begin{array}{l}\text { Efek samping potensial terkait pembedahan telah didiskusikan. Pasien diberi materi } \\
\text { bacaan dan nomer kontak untuk mendapat informasi yang dibutuhkan [25]. }\end{array}$ \\
\hline
\end{tabular}

Berbagi dengan kelompok diskusi atau klub jurnal antar kolega (utamanya interdisipliner) merupakan cara agar nyaman membicarakan seksualitas dan meningkatkan pengetahuan mengenai berbagai penyakit, terapi serta efeknya terhadap seksualitas. Kelompok dapat mendiskusikan latihan klarifikasi nilai atau artikel terkait seksualitas. Sebagai anggota tim yang diperlukan untuk konseling, dibutuhkan keterampilan, pengetahuan mengenai mitos seksualitas, pemahaman nilai dan sikap diri mengenai seks dan seksualitas, sebagaimana nilai dan sikap pasien. Konseling seksual sebaiknya mencakup evaluasi dan persiapan psikologis pra pembedahan, eksplorasi dinamika hubungan dengan pasangan, penilaian pasca histerektomi dan psikoterapi jika dibutuhkan. Efektivitas konseling dapat ditingkatkan melalui penyediaan informasi/saran melalui leaflet, materi audio/visual $[10,12]$.

Persiapan pra operatif baik untuk mengantisipasi ekspektasi negatif dari pembedahan, serta memahami dan menghargai makna emosional pembedahan terhadap pasien. Penting untuk menangani depresi atau kondisi psikiatri lain sebelum pembedahan dan, jika memungkinkan, menunda pembedahan sampai didapat respon terapi yang baik. Followup psikiatrik pasca histerektomi membantu memastikan stabilitas status psikiatrik $[11,17]$.
Konseling pra operasi dengan menunjukkan ketertarikan simpatik, mendengarkan seksama, menggunakan terminologi pasien dan menyesuaikan latar belakang pasien, serta terbagi atas:

Sesi I : Penjelasan pembedahan

Melalui diagram sederhana menjelaskan organ yang diangkat dan dampak pada menstruasi serta kemampuan memiliki anak. Perasaan "sebagai perempuan" atau femininitas maupun perasaan dan sensasi terkait sexual intercourse tidak harus berubah.

Sesi II : Petunjuk dalam mengontrol pemulihan diri

Hindari membandingkan pemulihan dengan perempuan lain dengan kondisi berbeda. Saat pasien merasa siap memulai suatu aktivitas, awali perlahan, lalu teruskan dan tingkatkan jika berjalan lancar. Kelelahan merupakan tanda untuk menunggu sedikit lagi sebelum mencoba kembali.

Sesi III : Ventilasi perasaan menjalani histerektomi

"Bagaimana perasaan anda menjalani
histerektomi?".

Sesi IV: Dampak histerektomi [17]. 


\begin{tabular}{|l|l|}
\hline \multicolumn{2}{|l|}{ Tabel 1.2 Model PLISSIT } \\
\hline P & $\begin{array}{l}\text { (Asesmen) termasuk pertanyaan seksualitas sebagai bagian penilaian umum atau pertanyaan } \\
\text { khusus terkait perjalanan penyakit dan terapi agar pasien/pasangan mengetahui bahwa aspek } \\
\text { seksual merupakan bagian perawatan holistik. }\end{array}$ \\
\hline $\begin{array}{l}\text { LI } \\
\text { (Limited }\end{array}$ & $\begin{array}{l}\text { (Edukasi) informasi efek penyakit dan pengobatan, termasuk kapan hubungan intim dapat } \\
\text { dilakukan kembali atau kemungkinan menopause. }\end{array}$ \\
\hline $\begin{array}{l}\text { SS } \\
\text { Suggecific }\end{array}$ & $\begin{array}{l}\text { (Konseling) membutuhkan pengetahuan mengenai kondisi khusus dan hubungannya terhadap } \\
\text { fungsi seksual, berbagai teknik, posisi dan alternatif untuk mencapai kepuasan seksual. }\end{array}$ \\
\hline $\begin{array}{l}\text { IT } \\
\text { (Intensive Therapy) }\end{array}$ & $\begin{array}{l}\text { Penanganan disfungsi seksual yang membutuhkan pelatihan khusus dalam psikoterapi, sex } \\
\text { therapy, crisis intervention dan modifikasi perilaku [10,25]. }\end{array}$ \\
\hline
\end{tabular}

\section{Permission:}

Banyak profesi kesehatan enggan menanyakan seksualitas pasien karena khawatir melanggar privasi. Namun seksualitas merupakan bagian kualitas hidup. Menilai seksualitas dan meresponnya penting dalam pengobatan holistik. Asesmen seksual menjadi bagian pemeriksaan rutin hampir tiap pasien, utamanya dengan penyakit kronis. Penilaian seksualitas rutin seperti sistem tubuh lain mengurangi rasa malu dengan menerimanya sebagai aspek normal perawatan kesehatan, memberi kesempatan pasien menceritakan kesulitan seksualnya dan klinisi mengajukan pertanyaan spesifik saat mencurigai efek samping seksual [10].

Mulai dari pertanyaan yang tidak terlalu intim (seperti fungsi peran) menuju yang lebih pribadi mengenai fungsi seksual. Hindari pertanyaan tertutup yang mengurangi kesempatan diskusi lebih jauh. Pertanyaan penilaian awal dapat dimulai pra atau pasca operasi, antara lain; bagaimana diagnosis/terapi mempengaruhi peran pasien sebagai istri/pasangan, bagaimana diagnosis/terapi mempengaruhi perasaan pasien terhadap dirinya sebagai perempuan, aspek apa dari seksualitas pasien yang terpengaruh oleh diagnosis/terapi, bagaimana diagnosis/terapi mempengaruhi fungsi seksual pasien. Fokus dari evaluasi medis seksual termasuk menentukan keluhan utama, status seksual, medis dan psikiatrik, riwayat keluarga dan psikoseksual, menilai hubungan serta ringkasan dan rekomendasi. Riwayat seksual lengkap biasanya tidak diperlukan kecuali penilaian awal mengindikasikan adanya masalah seksual [10,25].
Klinisi harap mengingat prinsip yang sama saat mendiskusikan seksualitas pasien dengan/tanpa pasangannya sebagaimana topik lainnya. Banyak pasien memiliki ekspektasi tidak realistik mengenai efektivitas terapi. Pasien butuh reassurance mengenai seksualitas pasca terapi. Hal ini menekankan kembali pentingnya peran klinisi sebagai edukator, sikap profesional terhadap diskusi ini, menjelaskan dengan jernih dan memastikan ijin pasien untuk menyertakan seksualitas dalam rencana penanganan. Contoh pertanyaan; "Apakah sudah ada yang membicarakan dengan anda bagaimana histerektomi dapat mempengaruhi kemampuan berhubungan seksual?" Teknik lain yang sering digunakan adalah unloading. Contohnya, "Banyak perempuan mengalami masalah saat berhubungan badan pasca histerektomi. Masalah apa yang anda temui terkait ini?" Unloading mengurangi kekhawatiran pasien saat mengetahui perempuan lain mengalami hal serupa $[10,25]$.

\section{Limited Information:}

Berikan informasi faktual sebagai respon atas pertanyaan maupun observasi. Waktu yang baik adalah sebelum pasien keluar rumah sakit pasca operasi. Luka operasi (trans-vaginal dan trans-abdominal) diharapkan sembuh dalam enam minggu dan dianggap aman untuk hubungan seksual. Sebelumnya, keintiman seksual baiknya dilakukan tanpa penetrasi. Contoh, "Sebaiknya menunggu sampai enam minggu untuk penetrasi, tapi mencium dan mencumbu diperbolehkan. Jangan khawatir perasaaan terangsang, karena hal itu tidak berbahaya bahkan mempercepat penyembuhan" [4,25]. 


\section{Specific Suggestion:}

Diskusi harus menyertakan posisi yang mengurangi dispareunia. Contohnya, "Jika dirasa menyakitkan, dapat dicoba posisi di atas untuk kontrol lebih baik terhadap kedalaman dan kekuatan penetrasi, serta mengurangi kemungkinan nyeri”. Dapat didiskusikan pula penurunan estrogen yang dapat menurunkan elastisitas dan lubrikasi vagina, serta hasrat dan orgasme, juga penggunaan lubrikan larut air, serta makna dari kehilangan uterus terhadap identitas diri $[10,25]$.

Histerektomi sebagai terapi kanker sering disertai radioterapi eksternal/internal. Efek sampingnya termasuk kelelahan, diare, vagina kering dan stenosis. Stenosis dapat dicegah dengan dilator atau vaginal intercourse teratur yang penting untuk fungsi seksual serta memudahkan pemeriksaan saat kontrol. Selain lubrikan, disarankan meningkatkan eksitasi sebelum penetrasi dan mengeksplorasi posisi baru yang memudahkan perempuan mengatur kedalaman penetrasi. Pasien juga didukung menggunakan cara lain mengekspresikan seksualitas, seperti sentuhan dan belaian. Kadang pasien harus menjalani kemoterapi yang dapat mengubah fungsi ovarium dan mengakibatkan menopause. Gejala menopause seperti hot flushes, vagina kering dan perubahan kulit ditambah efek samping kemoterapi sendiri dapat traumatis bagi perempuan, terutama jika mereka tidak mengerti sebelumnya kemungkinan ini. Vitamin E, lubrikan dan latihan Kegel dapat mengurangi gejala $[10,26,27]$.

\section{Intensive Therapy:}

Terapis seksual harus memahami dasar dan model dari psikoterapi marital, psikoterapi kelompok, cognitivebehavioral psychotherapy, assertive training dan teknik selfesteem reinforcement. Pasien nantinya diharapkan mampu mengidentifikasi perubahan potensial/aktual dalam seksualitas, fungsi seksual atau keintiman terkait penyakit dan terapi, mengekspresikan perasaan mengenai perubahan citra tubuh dan fungsi seksualnya, terlibat komunikasi terbuka dengan pasangan mengenai perubahan hasrat atau fungsi seksual, menggambarkan intervensi sesuai perubahan tersebut, serta mengidentifikasi sumber daya pribadi/komunitas untuk membantu menghadapi perubahan citra tubuh dan seksualitas. $[10,28]$.
Ansietas umumnya terjadi pada pasien dengan masalah seksual. Teknik relaksasi meditasi, yoga, taichi, Autogenic Training oleh Schultz dan Progressive Muscle Relaxation oleh Jacobson, serta latihan fisik teratur yang meningkatkan endorfin biasanya bermanfaat dan merupakan dasar program terapi seksual [6,28,29].

Hipnoterapi yang fokus pada situasi yang menimbulkan cemas, yaitu interaksi seksual, dapat ditambahkan untuk akselerasi efek intervensi psikoterapeutik. Hipnosis yang sukses memungkinkan pasien mengontrol gejala yang menurunkan self-esteem dan mengganggu keseimbangan psikologis [30].

Banyak pasien depresi memiliki masalah seksual, sebaliknya masalah seksual dapat menimbulkan depresi sehingga butuh peresepan antidepresan. Peresepan ansiolitik yang benar sangat bermanfaat terutama di awal proses. Terapi sulih hormon dengan estrogen dan testosteron dosis rendah cukup efektif, dimana estrogen dimana dalam bentuk cincin/tablet vagina dan tidak meningkatkan kadar dalam darah $[28,30]$.

Terapi perilaku awalnya dikembangkan untuk fobia. Terapis berasumsi bahwa disfungsi seksual merupakan perilaku maladaptif yang dipelajari. Dengan teknik desensitisasi, terapis dan pasien menyusun hierarki dari situasi yang menimbulkan ansietas mulai paling tidak mengancam (contoh: memikirkan berciuman) sampai paling mengancam (contoh: penetrasi penis). Melatih asertivitas sangat bermanfaat dalam mengekspresikan kebutuhan seksual dengan terbuka. Pasien didorong menanyakan permintaan seksual dan menolak permintaan yang tidak masuk akal. Latihan meminta dilakukan di rumah dengan hierarki dari aktivitas yang terbukti paling menyenangkan dan sukses dilakukan sebelumnya [30].

Terapi kelompok memberi support system kuat untuk pasien yang malu, cemas atau merasa bersalah mengenai masalah seksual tertentu, serta bermanfaat meluruskan mitos seksual dan menyediakan informasi akurat mengenai anatomi seksual, fisiologi dan variasi perilaku. Teknik role-playing atau psikodrama dapat pula digunakan. Terapi ini tidak sesuai bagi pasien dengan depresi berat atau pasangan tidak kooperatif. Kelompok dapat beranggotakan pasien dengan masalah serupa, atau masalah berbeda dengan jenis kelamin sama, maupun terdiri atas pasangan suami-istri [30]. 
Salah satu modalitas paling efektif merupakan integrasi terapi seks dengan psikoterapi berorientasi psikodinamika dan psikoanalitika. Periode yang lebih lama memungkinkan pembelajaran atau pembelajaran ulang mengenai kepuasan seksual dengan realitas keseharian pasien saat ini. Materi dan dinamika pasien seperti terapi psikoanalitika, yaitu mimpi, takut dihukum, perasaan agresif, sulit percaya pasangan, takut keintiman, perasaan oedipal dan ketakutan mutilasi genital. Pertimbangkan waktu optimal bagi terapi ini dengan kemampuan pasien menolerir pendekatan langsung yang fokus pada kesulitan seksual mereka [30].

Dual-Sex Therapy dikembangkan Master dan Johnson ini didasari konsep bahwa marital unit terdiri dari diad sebagai obyek terapi. Jika terdapat disfungsi pada salah satunya, maka keduanya harus berpartisipasi dalam terapi karena sama-sama terlibat dalam situasi seksual yang distressing. Masalah seksual sering merefleksikan disharmoni pada area lain perkawinan. Terapi ini bersifat jangka pendek dan berorientasi perilaku. Dasarnya adalah sesi roundtable empat arah, dengan terapis pria dan perempuan bersikap edukatif, mengklarifikasi dan mendiskusikan aspek fisiologis dan psikologis dari fungsi seksual. Terapis merefleksikan situasi yang tampak tanpa interpretasi dinamika yang mendasari. Refleksi tanpa distorsi ini mengoreksi perspektif miopik sempit dari pasangan sehingga memutus pola hubungan dan komuniksi yang destruktif $[28,30]$.

Terapis menyarankan aktivitas seksual spesifik di rumah untuk tiap permasalahan tertentu. Latihan awal biasanya fokus pada peningkatan kesadaran sensoris terhadap sentuhan, pandangan, suara dan bau. Pasangan dilarang melakukan aktivitas seksual selain yang ditugaskan terapis. Intercourse tidak disarankan di awal hingga pasien belajar memberi dan menerima kenikmatan tanpa tekanan penetrasi, melakukan komunikasi non-verbal yang memuaskan, serta memahami bahwa foreplay merupakan alternatif intercourse dan orgasme yang menyenangkan [30].

Selama latihan, pasangan diberi banyak reinforcement untuk mengurangi kecemasan dan penggunaan fantasi sebagai distraksi atas obsesi terhadap performance. Kebutuhan kedua pasangan dipertimbangkan, jika salah satu tereksitasi secara seksual saat latihan, yang lain dianjurkan memberikan orgasme secara oral atau manual. Resistensi, seperti mengaku lelah atau tidak ada waktu, kerap terjadi dan akan ditangani oleh terapis. Isu citra tubuh, takut disentuh dan kesulitan menyentuh diri sendiri sering pula muncul. Pasangan lalu diinstruksikan mencoba variasi posisi dan teknik stimulasi genital/non-genital, dilanjutkan dengan instruksi untuk intercourse sebenarnya. Tiap periode latihan baru akan diikuti sesi psikoterapi, mendiskusikan masalah dan kepuasan seksual maupun area kehidupan lainnya [30].

Teknik atau latihan lain yang kerap digunakan antara lain, dilator atau jari pada kasus dispareunia atau vaginismus; teknik "1-2-3" dimana pasangan mengobservasi masturbasi pertama yang dilakukan pria, lalu perempuan, kemudian mempraktekkan secara mutual; teknik 'Stop \& Go' yang memperkenalkan istirahat untuk mengatasi kecemasan penetrasi atau menunda respon orgasme yang terlalu dini; 'Bridge Maneuver' yang membantu perempuan mencapai orgasme dengan bantuan stimulasi klitoris sebelum penetrasi; vibrator untuk relaksasi; mengunjungi sex shop untuk melepas ketegangan dan ketakutan; latihan otot pubocoxigeus, pijat erotik dan oral seks; teknik VESTAF (Void routine melalui perjalanan, Excercise your body, Time atau mengatur waktu, Abide hunger dengan makan sehat dan seimbang, Fantasy yang menginduksi rekreasi dan komunikasi) [6,28,30].

\section{RINGKASAN}

Seksualitas pasca histerektomi dipengaruhi faktor psikologis selain fisiologis (anatomi dan hormonal). Perubahan kualitatif pada sensasi dan kenikmatan seksual sulit dinilai reliabilitasnya. Banyak perempuan yang mendeskripsikan kehidupan seksual pasca histerektomi dipengaruhi masalah hubungan dengan pasangan atau keluarga, komplikasi nonseksual pembedahan, gangguan mental sebelumnya, trauma seksual dan disfungsi seksual pasangan. Penting untuk mengenali fungsi seksual sebagai penyebab utama kecemasan pada perempuan menjelang histerektomi. Meski histerektomi dapat memperbaiki kesehatan dan fungsi seksual banyak perempuan, beberapa mengalami perburukan signifikan. Penilaian pra operatif menyeluruh dan intervensi psikoterapeutik oleh psikiater yang kompeten mengurangi efek negatif tersebut. 


\section{DAFTAR PUSTAKA}

[1] Lefebvre G, Allaire C, Jeffrey J \& Vilos G, Hysterectomy; Clinical Practice Guideline. Toronto: Society of Obstetricians and Gynaecologist of Canada, 2002.

[2] Cohen SM, Linenberger HK, Wehry LE, Welz HK, "Recovery After Hysterectomy: A Year-Long Look," webmed Gentral.com, vol. 2, no. 3, pp. 1-10, 2011.

[3] Stotland NL \& Stewart DE, Psychological Aspects of Women's Health Care: The Interface between Psychiatry and Obstetrics \& Gynecology $2^{\text {nd }} e d$. Washington DC: American Psychiatric Press, Inc, pp. 283-304, 2001.

[4] Wallach EE \& Eisenberg E, Hysterectomy: Exploring Your Options. Baltimore: The Johns Hopkins University Press, 2003.

[5] Rhodes JC, Kjerulff KH, Langenberg PW \& Guzinaki GM, Hysterectomy and Sexual Functioning, 282nd ed. J Am Med Assoc 282, pp.1034-41,1999.

[6] Schiavi RC, "Forum Psychiatry And Human Sexuality Psychiatrists' role in the management of sexual disorders," Curr Opinion in Psychiatry, vol. 12, no. 4, pp. 267-9, 2000.

[7] Lin HL, Chou HH, Liu CY, et al, "The Role of Consulting Psychiatrists of Obstetric and Gynecologic Inpatients," Chang Gung Med J, vol. 34, no. 1, pp. 5763, 2010.

[8] Roovers JWR, van der Bom JG \& Huub C, "Hysterectomy and Sexual Wellbeing: Prospective Observational Study of Vaginal Hysterectomy, Subtotal Abdominal Hysterectomy, and Total Abdominal Hysterectomy," Br. Med J, no. 327, pp. 774-8, 2003.

[9] Meston \& Bradford, "A brief review of the factors influencing sexuality after hysterectomy.pdf," Sexual \& Relationship Ther, vol. 19, no. 1, 2004.

[10] Wilmoth MC, Sexuality. In Lubkin IM (Ed.) Chronic Illness, Impact and Intervention (8th ed). Burlington: Jones \& Bartlett Learning, 2013.

[11] Burt VK \& Hendrick VC, Clinical Manual of Women's Mental Health. Washington DC: American Psychiatric
Publishing, Inc, 2005.

[12] Mokate T, Wright C \& Mander T, "Hysterectomy and Sexual Function," J Br. Menopause Soc, vol. 12, no. 4, pp. 153-7, 2006.

[13] Alexander DA, Naji AA, Pinion SB, et al , "Randomised Trial Comparing Hysterectomy with Endometrial Ablation for Dysfunctional Bleeding: Psychiatric and Psychological Aspects," Br. Med J, no. 312, pp. 280-4, 1995.

[14] Thakar R, Ayers S, Clarkson P, et al, "Outcomes After Total versus Subtotal Abdominal Hysterectomy," $N$ Engl J Med, vol. 347, no. 17, pp. 1318-25, 2002.

[15] Maas CP, Weijenborg PTM, ter Kuile MM, "The Effect of Hysterectomy on Sexual Functioning," Ann Rev Sex Res., no. 14, pp. 83-113, 2003.

[16] Dennerstein L, Koochaki P, Barton I \& Graziottin A, "Hypoactive sexual desire disorder in menopausal women: A survey of Western European women," $J$. Sex. Med., vol. 3, no. 2, pp. 212-222, 2006, doi: 10.1111/j.1743-6109.2006.00215.x.

[17] Judith HP, "Psychosocial Problems of Women Who had Undergone Hysterectomy (A Pilot Study) Kerala Research Programme on Local Level Development (KRPLLD) Centre for Development Studies Psychosocial Problems of Women who had Undergone Hysterectomy (A Pilot Study)," Kerala Res. Program. Local Lev. Dev. Cent. Dev. Stud., vol. 1, no. 1, pp. 139, 2003.

[18] Cohen SM, Hollingsworth AO, Rubin M, et al, "Psychosocial Adaptation During Recovery From Hysterectomy," WebmedCentral Obstet Gynecol, vol. 2, no. 3, pp. 1-8, 2011.

[19] Bayram GO \& Beji NK, "Psychosexual Adaptation and Quality of Life After Hysterectomy,” Sex Disabil, no. 28, pp. 3-13, 2010.

[20] Kjerulff KH, Langenberg PW, Rhodes JC, et al, "Effectiveness of Hysterectomy," Obs. Gynecol, no. 95, pp. 319-26, 2000.

[21] Walsgrove H, "Hysterectomy," Nurs. Stand., vol. 15, no. 29, pp. 47-53, 2001.

[22] Farquhar MC \& Steiner CA, "Hysterectomy Rates in the United States 1990-1997," Am Coll Obs. Gynecol, 
vol. 99, no. 2, pp. 229-34, 2002.

[23] Meston CM, “Aging and Sexuality," West J Med, no. 167, pp. 285-90, 1997.

[24] Katz A, "Sexuality after Hysterectomy," J Obs. Gynec $N N$, vol. 31, no. 3, pp. 256-62, 2002.

[25] Katz A, "Sexuality and hysterectomy: Finding the right words," Am. J. Nurs., vol. 105, no. 12, pp. 65-68, 2005, doi: 10.1097/00000446-200512000-00035.

[26] Kornstein SG \& Clayton AH, Women's Mental Health: A Comprehensif Textbook. New York: The Guilford Press, pp. 376-81, 2002.

[27] Bancroft J, Human Sexuality and Its Problems. London: Churchill Livingston Elsevier, pp.120-38, 2009.

[28] Hernandez-Serrano R, Advances in the Treatment of Sexual Disorders. Hamburg: Presented at the 11th World Congress of Psychiatry, 1999.

[29] Ozdemir F \& Pasinlioglu T, “The Effects of Training and Progressive Relaxation Exercises On Anxiety Level After Hysterectomy,” New J. Med., pp. 102-107, 2009.

[30] Sadock BJ \& Sadock VA, Kaplan \& Sadock's Synopsis of Psychiatry: Behavioral Sciences/Clinical Psychiatry (10th ed). New York: Lippincott Williams \& Wilkins, 2007. 